\title{
ANTERIOR TRANSPOSITION VERSUS IN SITU NEUROLYSIS IN CUBITAL TUNNEL SYNDROME: A COMPARISON BASED ON FUNCTIONAL AND ELECTRO-DIAGNOSTIC EVALUATION
}

\author{
KÜBITAL TÜNEL SENDROMUNDA ANTERIOR TRANSPOZISYON ILE IN SITU \\ GEVŞETMENIN FONKSIYONEL VE ELEKTRODIAGNOSTIK SONUÇLARININ \\ KARŞILAŞTIRILMASI
}

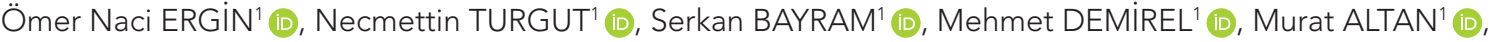 \\ Ahmet SALDUZ1 (D, Hayati DURMAZ1 (D)
}

${ }^{1}$ Istanbul University Istanbul Faculty of Medicine, Department of Orthopedics and Traumatology, Istanbul, Turkey

ORCID IDs of the authors: Ö.N.E. 0000-0001-6848-6930; N.T. 0000-0003-4994-5059; S.B. 0000-0001-7651-1200;

M.D. 0000-0003-1131-7719; M.A. 0000-0001-5602-1458; A.S. 0000-0001-9448-6416; H.D. 0000-0002-2571-6617

Cite this article as: Ergin ON, Turgut N, Bayram S, Demirel M, Altan M, Salduz A et al. Anterior transposition versus in situ neurolysis in cubital tunnel syndrome: a comparison based on functional and electro-diagnostic evaluation. J Ist Faculty Med 2020;83(3):204-8. doi: 10.26650/IUITFD.2019.0084

\begin{abstract}
Objective: The aim of the present study is to compare that results of in situ neurolysis and anterior transposition procedures both clinically and electro-diagnostically in those patients diagnosed with cubital tunnel syndrome.
\end{abstract}

Material and Methods: Twenty of 34 patients who had undergone both preoperative, postoperative electromyogram (EMG) nerve conduction tests and regular follow-up were included in our study. Then, the patients were divided into 2 groups - in situ neurolysis (group A) and anterior transposition (group B). Both groups were compared based on modified Bishop functional scores, preoperative and postoperative EMG parameters.

Results: There was no statistically significant difference in relation to EMG parameters between the two groups. When comparing preoperative and postoperative EMG results, in the patients with anterior transposition surgery 'elbow to below-elbow' and 'below-elbow to wrist' motor conduction velocity was increased significantly ( $p=0.018$ and 0.04$)$. While the average Bishop score was 7.9 in group $A$ and 9.3 in group B, there was no statistical difference between the two groups in terms of Bishop Scores.

Conclusion: In the management of cubital tunnel syndrome, the choice of technique doesn't affect the functional results; however, anterior transposition of the nerve provides better recovery in 'elbow to below-elbow' and 'below-elbow to wrist' motor conduction velocity.

Keywords: Ulnar nerve, EMG, Anterior transposition

\section{ÖZET}

Amaç: Bu çalışmanın amacı, kübital tünel sendromu olan hastalarda in situ gevşetme ve anterior transpozisyon prosedürlerinin klinik ve elektrodiagnostik sonuçlarının karşılaştırılmasıdır.

Gereç ve Yöntemler: Çalışmamıza preoperatif ve postoperatif elektromiyogram (EMG) sinir iletim testi olan düzenli takip uygulanan 34 hastanın 20'si dahil edildi. Hastalar in situ gevşetme (A grubu) ve anterior transpozisyon (B grubu) olarak 2 gruba ayrıldı. Her iki grup modifiye Bishop fonksiyonel skorları, preoperatif ve postoperatif EMG parametreleri kullanılarak karşılaştıııldı.

Bulgular: Iki grup arasında EMG parametrelerinin ilişkisi açısından istatistiksel olarak anlamlı fark saptanmadı. Preoperatif ve postoperatif EMG sonuçları karşılaştırıldığında, anterior transpozisyon uygulanan grupta "dirsek- dirsek altı" ve "dirsek altı-el bileği" motor iletkenlik hızının anlamlı olarak arttığı saptandı ( $p=0,018$ ve 0,04 ). Bishop skoru A grubunda ortalama 7,9 iken, B grubunda 9,3 olarak saptandı. Bishop skorları açısından iki grup arasında istatistiksel olarak anlamlı fark saptanmadı.

Sonuç: Kübital tünel sendromunun tedavisinde, teknik seçimi fonksiyonel sonuçları etkilememektedir; Bununla birlikte, sinirin anterior transpozisyonu, "dirsek- dirsek altı" ve "dirsek altı-el bileği" motor iletim hızında daha fazla iyileşme sağladığı saptandı.

Anahtar Kelimeler: Ulnar sinir, EMG, Anterior transpozisyon

Corresponding author/iletişim kurulacak yazar: dr.serkanbayram89@gmail.com

Submitted/Başvuru: 01.11.2019• Revision Requested/Revizyon Talebi: 04.11.2019•

Last Revision Received/Son Revizyon: 12.02.2020 • Accepted/Kabul: 04.03.2020 • Published Online/Online Yayın: 05.06.2020

(C)Telif Hakkı $2020 \mathrm{~J}$ Ist Faculty Med - Makale metnine jmed.istanbul.edu.tr web sayfasından ulaşılabilir.

(C) Copyright 2020 by J Ist Faculty Med - Available online at jmed.istanbul.edu.tr 


\section{INTRODUCTION}

Cubital tunnel syndrome is the second most common compressive neuropathy of the upper extremity following carpal tunnel syndrome, which is characterized by pain around the elbow and paresthesia in ulnar side of the hand $(1,2)$. Miscellaneous surgical treatment methods have been described in the management of this common entity in the literature, the leading method of which is simple decompression, also known as in situ neurolysis. Whether open surgically or endoscopically, decompression of the cubital tunnel may be performed. Either treatment modality basically focuses on release of the Osborne ligament. Besides decompression of cubital tunnel syndrome, the transposition of the ulnar nerve to the anterior side of the elbow is frequently used as a procedure in the management of this compressive neuropathy. Three anterior transposition techniques have been described: submuscular, intramuscular and subcutaneous. Apart from these, medial epicondylectomy may be employed as well. Regarding a change of motor nerve conduction velocity among these surgical techniques, clinical and functional results have not yet shown any superiority in any of these (3); however, the literature indicates good functional results following surgical treatment (4).

The main aim of the present study is to compare that results of in situ neurolysis and anterior transposition procedures as both clinically and electro-diagnostically in those patients diagnosed with cubital tunnel syndrome.

\section{MATERIAL AND METHOD}

After approval of the institutional review board, the charts of 34 patients who have been treated for cubital tunnel syndrome in our department were reviewed between 2004 and 2015. The inclusion criteria included patients who had undergone surgery due to cubital tunnel syndrome and who had regular follow-up data at least 1 year after the surgery with pre-and post- operative EMG tests. The exclusion criteria included presence of osteoarthrosis or osteophytes in the anteroposterior and lateral radiographs of the affected elbow, previous surgery for cubital syndrome, related to cervical radiculopathy, carpal tunnel syndrome, ulnar tunnel syndrome, thoracic outlet syndrome, having no follow-up data for at least 1 year, having no EMG test.

Fourteen patients who did not meet the criteria listed above were excluded. After exclusion, we had 20 patients (15 females, 5 males) treated surgically due to cubital tunnel syndrome, confirmed by preoperative EMG test. The mean age of the patients was 45.8 (29-71) years. The left side was affected in 15 patients, the right side was affected in 5 patients. The average follow-up duration was 64.8 (range 13-147) months. The severity of the ulnar neuropathy was Grade II in all patients according to the McGowan classification (5). In the physical examination; in addition to pain in the medial side of the elbow and forearm, sensorial deficit of the entire $5^{\text {th }}$ finger and medial half of the $4^{\text {th }}$ finger was observed in all patients preoperatively. Some of the patients had weakness and wasting in the interosseous muscles. Functional status of patients was evaluated by a modified Bishop score (6). Surgical technique was chosen as simple in situ neurolysis in 9 patients and anterior subfascial transposition in 11 patients according to the surgeon preferences.

Motor and sensorial conduction velocity 'from the elbow to below-elbow' and 'from the below-elbow to wrist' respectively was measured both preoperatively and postoperatively. Electro diagnostic studies were carried out and interpreted by a professional rehabilitation physician at our institution. Postoperative EMG was obtained at least 6 months after surgery. In nerve conduction studies, the ulnar nerve was stimulated by single pulses of $0.2 \mathrm{~ms}$ duration at the wrist, $5 \mathrm{~cm}$ below as well as $10 \mathrm{~cm}$ above the elbow. The reference electrode was fixed to the base of the fifth finger. Stimulus strength was increased until a maximum CMAP could be recorded. Sensorial and motor conduction velocities were recorded with bipolar surface electrodes from the abductor digiti minimi muscle (ADM) with the active electrode placed over the muscle belly.

Patients were divided into two groups as simple in situ neurolysis (Group A), anterior transposition (Group B). Group A included 9 patients with a mean age of 44.9 (3452) years. Group B included 11 patients with a mean age of 50.3 (30-72) years. The mean follow-up period after the operation was 55 (12-147) months in group $A$ and 73.8 (17-105) months in group B.

The Mann-Whitney $U$ test was used in comparison of functional status based on the Bishop score between the groups. The paired Student's t-test was used, in order to compare preoperative and postoperative results of EMG tests. The results were assessed statistically significant in $95 \%$ confidence interval and $p<0.05$ level.

\section{RESULTS}

In group $A$, while the mean sensorial conduction velocity was $44.4 \mathrm{~m} / \mathrm{s}$ preoperatively, postoperative mean values were found to be $55.3 \mathrm{~m} / \mathrm{s}$. Mean elbow to below-elbow motor conduction velocity was $43.5 \mathrm{~m} / \mathrm{s}$ preoperatively and $49.1 \mathrm{~m} / \mathrm{s}$ postoperatively. Below-elbow to wrist motor conduction velocity was $54.1 \mathrm{~m} / \mathrm{s}$ preoperatively and 59 $\mathrm{m} / \mathrm{s}$ postoperatively. In group A, although postoperative values were increased to preoperative values, there was no statistically significant difference ( $p>0.05)$ (Figure 1).

In group B, preoperative with postoperative main values of sensorial conduction velocity were, $54 \mathrm{~m} / \mathrm{s}$ and 55.8 $\mathrm{m} / \mathrm{s}$ respectively ( $>0.05$ ). While preoperatively mean 'el- 


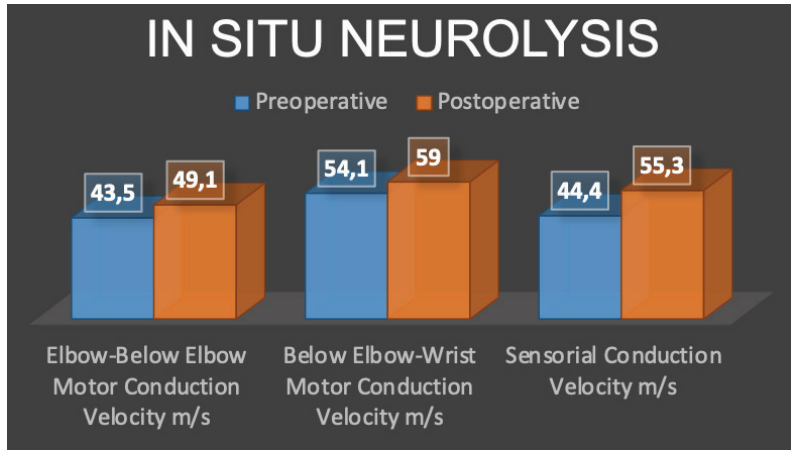

Figure 1: The results of electro diagnostic studies for simple in situ neurolysis. There was no statistical difference between pre and post-operative values.

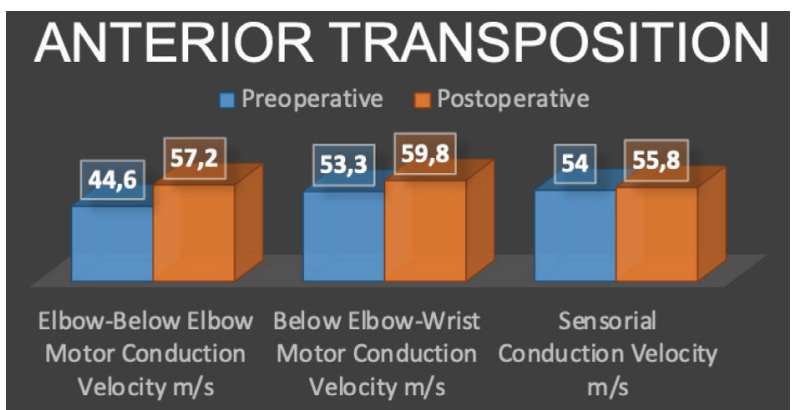

Figure 2: The results of electro diagnostic studies for anterior decompression. In the postoperative EMG results the 'elbow to below-elbow' and 'below-elbow to wrist' motor conduction velocity was increased significantly compared to preoperatively ( $p=0.018$ and 0.04$)$.

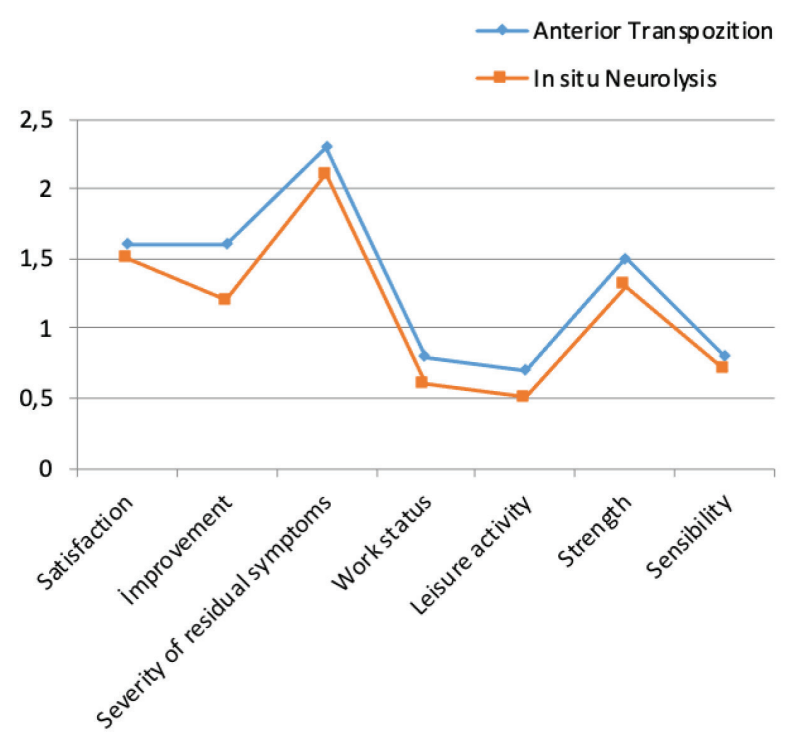

Figure 3: The comparison of the postoperative Bishops score is shown in the graph. There was no statistical difference between groups. bow to below-elbow' motor conduction velocity was 44.6 $\mathrm{m} / \mathrm{s}$, it was $57.2 \mathrm{~m} / \mathrm{s}$ postoperatively. Mean below-elbow to wrist motor conduction velocity was preoperatively $53.3 \mathrm{~m} / \mathrm{s}$ and postoperatively $59.8 \mathrm{~m} / \mathrm{s}$. When comparing preoperative with postoperative EMG results, in group $B$, the 'elbow to below-elbow' and 'below-elbow to wrist' motor conduction velocity was increased significantly $(p=0.018$ and 0.04 ) (Figure 2).

There was no statistically significant difference in terms of EMG parameters between the two groups. While the average Bishop score was as 7.9 in group $A$ and 9.3 in group $B$, there was no statistical differences between the two groups in terms of Bishop scores (Figure 3).

\section{DISCUSSION}

Even though cubital tunnel syndrome is a well-defined compression neuropathy, its treatment remains controversial. It is unclear which treatment modality should be preferred in which period in the management of cubital tunnel syndrome; however, there is a consensus with respect to primary treatment being non-surgical methods. As a general conception, if nonsurgical treatment fails, surgical treatment is indicated (7-9).

There are a variety of treatment modalities in the management of cubital tunnel syndrome. Example of this includes epicondylectomy, in-situ decompression (in-situ neurolysis), anterior transposition of the ulnar nerve. However, there is no consensus in relation to the best surgical treatment procedure in the literature. The surgical treatment process is conducted in view of physicians' experiences and preferences $(7,10,11)$. Operative treatment was recommended, if patients suffered from intrinsic atrophy or considerable hand weakness and had clinical symptoms of pain, or weakness following conservative treatment.

Although medial epicondylectomy is considered as a standard procedure in the surgical treatment of cubital tunnel syndrome, in situ neurolysis and anterior transposition of the ulnar nerve have been performed more often recently. Compressive tissues, especially Osborne's ligament, are released in simple decompression; another method covers anterior transposition of the ulnar nerve to subcutaneous or submuscular area following release of compressive tissues. These two methods, simple decompression and anterior transposition of the nerve, are frequently employed in our clinic as well. Therefore, we aimed to compare the functional and EMG test results of two surgical treatment methods.

There are many clinical studies comparing the advantages and disadvantages of these methods. In situ decompression basically requires a simpler technique and less invasive dissection compared to anterior transposition of the nerve. Thus; it is believed that in situ neurolysis dimin- 
ishes the risk of vascular compromise of the ulnar nerve. In light of the Gelberman et al. findings, anterior transposition of the ulnar nerve does not effectively relieve the symptoms (12). However, more recently, some clinical studies have shown that anterior transpositions of the ulnar nerve were less routinely done. Furthermore, it has been suggested that anterior transposition of the nerve may pose some problems such as injury of the medial antebrachial cutaneous nerve and vascular compromise of the ulnar nerve. An experimental study by Ogata et al. showed that regional blood supply may be disturbed for a minimum of 3 days (13). In another study, it was proposed that in situ neurolysis should be the first option to manage cubital tunnel syndrome because, there was no significant difference regarding results of either technique and much fewer complications related to in situ decompression (14).

In another study by Bartels et al. each group was found similar in terms of effectivity of the treatment (15). Nevertheless, complication rates were $23 \%$ and $7 \%$ respectively, in the anterior transposition and decompression group. Therefore, they stated that if there was no preoperative subluxation, performing only in situ decompression would be necessary. Related to this, some studies also found no significant difference $(6,16,17)$. In one of these studies, Keiner et al. suggested that, in situ decompression should be preferred because of being less invasive than anterior transposition of the nerve (17). Besides these, in two meta-analysis composed of 4 randomized clinical studies in terms of comparison of either technique, the authors found no significant difference. However, it is observed that regardless of type of transposition of the ulnar nerve (sub-muscular or sub-cutaneous), anterior transposition procedure can provide satisfactory results $(3,18)$.

Conversely, some authors advocated that anterior transposition of the nerve should be performed in the management of the cubital tunnel syndrome because, to achieve more satisfactory results, the nerve should be carried to a more convenient tissue region, and tension of the nerve should be decreased. The core point is that removal of the compressive forces in a flexed elbow is possible only performing anterior transposition of the nerve, in situ decompression does not address this problem. Although it is known that vascular compromise can be much more frequent when performing anterior transposition, Seyfettinoğlu et al. stated that vascular compromise following anterior transposition had no influence over functional results of the nerve (19). Because of this, the vascular compromise related to anterior transposition remains controversial in the literature. To enlighten this issue, new prospective studies are required. In spite of being a treatment modality in the management of cubital tunnel syndrome, medial epicondylectomy occupies a limited area. Successful results related to medial epicondylectomy have been published; however, the pain around the medial epicondyle remains a worrying problem $(1,20)$.

In a recent meta-analysis, there was no difference regarding motor conduction velocity and clinical results (20). In our study, 'elbow to below-elbow' and 'below-elbow to wrist' motor conduction velocity was significantly increased in the anterior transposition group (respectively p: 0.018 and 0.04 ), when comparing preoperative and postoperative electro diagnostic results. In the simple in situ neurolysis group, in spite of postoperative values being higher than preoperative values, no significant difference was observed. In a similar way, there was no significant difference in relation to sensorial conduction velocity, despite increased postoperative values. This results can be beneficial to choosing the anterior transposition technique.

The modified Bishop score was used to evaluate functional condition of the patients. In view of the Bishop scores, there was no significant difference, when comparing anterior transposition and simple in situ neurolysis group. According to these results, no functional effect of increased postoperative motor conduction velocity in anterior transposition group was observed in the clinical process.

There are several limitations to this study. Firstly, we utilized one outcome measure, the modified Bishop scale in order to evaluate the clinical outcomes after surgical treatment; however, this scoring system has no reliable outcome parameter to assess cubital tunnel syndrome. Second, our investigation is a retrospective clinical study. When taking the literature into account, prospective studies comparing each treatment modality are necessary. Third, this study includes only a limited number of cases with a relatively short-term follow-up period. In our series, the interval between the onset of symptoms and surgeries was relatively longer than other studies.

\section{CONCLUSION}

In the management of cubital tunnel syndrome, choice of technique doesn't affect the functional results; however, anterior transposition of the nerve provides better recovery in the 'elbow to below-elbow' and 'below-elbow to wrist' motor conduction velocity. As a result, each technique has advantages and disadvantages. According to our opinion, anterior transposition of the nerve can be preferred in terms of obtaining better motor recovery.

Acknowledgements: We thank the department of Neurology for their participation in the electrodiagnostic tests and analysis.

Ethics Committee Approval: Ethics committee approval was not received due to the retrospective nature of the study. 
Informed Consent: Written consent was obtained from the participants.

Peer Review: Externally peer-reviewed.

Author Contributions: CConception/Design of Study- Ö.N.E., S.B., M.A., A.S.; Drafting Manuscript- N.T., S.B., M.D.; Final Approval and Accountability- Ö.N.E., N.T., S.B., M.D., M.A., A.S., H.D.

Conflict of Interest: Authors declared no conflict of interest.

Financial Disclosure: Authors declared no financial support.

Teşekkür: Elektrodiagnostik testlere ve analizlere katıldıkları için Nöroloji bölümüne teşekkür ediyoruz.

Etik Komite Onayı: Retrospektif çalışma olduğundan etik komite onayı alınmamıştır.

Bilgilendirilmiş Onam: Katılımcılardan bilgilendirilmiş onam alınmıştır.

\section{Hakem Değerlendirmesi: Dış bağımsız.}

Yazar Katkıları: Çalışma Konsepti/Tasarım- Ö.N.E., S.B., M.A., A.S.; Yazı Taslağı- N.T., S.B., M.D.; Son Onay ve SorumlulukÖ.N.E., N.T., S.B., M.D., M.A., A.S., H.D.

Çıkar Çatışması: Yazarlar çıkar çatışması beyan etmemişlerdir.

Finansal Destek: Yazarlar finansal destek beyan etmemişlerdir.

\section{REFERENCES}

1. Muermans S, De Smet L. Partial medial epicondylectomy for cubital tunnel syndrome: outcome and complications. J Shoulder Elbow Surg 2002;12(2):248-52. [CrossRef]

2. Soltani AM, Best MJ, Francis CS, Allan BJ, Panthaki ZJ. Trends in the surgical treatment of cubital tunnel syndrome: an analysis of the national survey of ambulatory surgery database. J Hand Surg Am 2013;38(8):1551-6. [CrossRef]

3. Zlowodzki M, Chan S, Bhandari M, Kalliainen L, Schubert W. Anterior transposition compared with simple decompression for treatment of cubital tunnel syndrome, J Bone Joint Surg Am 2007;89(12):2591-8. [CrossRef]

4. Cutts S. Cubital tunnel syndrome. Postgrad Med J 2007; 83(975):28-31. [CrossRef]

5. McGowan AJ. The results of transposition of the ulnar nerve for traumatic ulnar neuritis. J Bone Joint Surg $\mathrm{Br}$ 1950;32(3);293-301. [CrossRef]

6. Nabhan A, Ahlhelm F, Kelm J, Reith W, Schwerdtfeger K, Steudel WI. Simple decompression or subcutaneous anterior transposition of the ulnar nerve for cubital tunnel syndrome. J Hand Surg Br 2005;30(5):521-4. [CrossRef]

7. Chan RC, Paine KW, and Varughese G. Ulnar neuropathy at the elbow: comparison of simple decompression and anterior transposition. Neurosurgery 1980;7(6):545-50. [CrossRef]
8. Glowacki KA, Weiss AP. Anterior intramuscular transposition of the ulnar nerve for cubital tunnel syndrome. J Shoulder Elbow Surg 1997;6(2);89-96. [CrossRef]

9. Oskay D, Meriç A, Kirdi N, Firat T, Ayhan C, Leblebicioğlu G. Neurodynamic mobilization in the conservative treatment of cubital tunnel syndrome: long-term follow-up of 7 cases. J Manipulative Physiol Ther 2010;33(2):156-63. [CrossRef]

10. Dellon AL, Coert JH. Results of the musculofascial lengthening technique for submuscular transposition of the ulnar nerve at the elbow. J Bone Joint Surg Am 2003:85(7):1314-20. [CrossRef]

11. Lascar T, Laulan J. Cubital tunnel syndrome: a retrospective review of 53 anterior subcutaneous transpositions. J Hand Surg Br 2000;25(5):453-6. [CrossRef]

12. Gelberman RH, Yamaguchi K, Hollstien SB, Winn SS, Heidenreich FP Jr, Bindra RR, Hsieh P, Silva MJ. Changes in interstitial pressure and cross-sectional area of the cubital tunnel and of the ulnar nerve with flexion of the elbow. An experimental study in human cadavera. J Bone Joint Surg Am 1998;80(4):492-501. [CrossRef]

13. Ogata K, Manske PR, Lesker PA. The effect of surgical dissection on regional blood flow to the ulnar nerve in the cubital tunnel. Clin Orthop Relat Res 1985;193:195-8. [CrossRef]

14. Biggs M, Curtis JA. Randomized, prospective study comparing ulnar neurolysis in situ with submuscular transposition. Neurosurgery 2006;58(2);296-304. [CrossRef]

15. Bartels RH, Verhagen WI, van der Wilt GJ, Meulstee J, van Rossum LG, Grotenhuis JA. Prospective randomized controlled study comparing simple decompression versus anterior subcutaneous transposition for idiopathic neuropathy of the ulnar nerve at the elbow: Part 1. Neurosurgery 2005;56(3);522-30. [CrossRef]

16. Gervasio O, Gambardella G, Zaccone C, Branca D. Simple decompression versus anterior submuscular transposition of the ulnar nerve in severe cubital tunnel syndrome: a prospective randomized study. Neurosurgery 2005;56(1):108-17. [CrossRef]

17. Keiner D, Gaab MR, Schroeder HW, Oertel J. Comparison of the long-term results of anterior transposition of the ulnar nerve or simple decompression in the treatment of cubital tunnel syndrome-a prospective study. Acta Neurochir (Wien) 2009;151(4):311-5. [CrossRef]

18. Macadam SA, Gandhi R, Bezuhly M, Lefaivre KA. Simple decompression versus anterior subcutaneous and submuscular transposition of the ulnar nerve for cubital tunnel syndrome: a meta-analysis. J Hand Surg Am 2008;33(8):1314:.e1-12. [CrossRef]

19. Seyfettinoğlu F, Karaer A, Sertöz Z, Dülgeroğlu A, Koruyucu $M B$, Bora OA. Assessment of the effects of surgical treatment options for cubital tunnel syndrome on the ulnar nerve by USG and EMG. Eklem Hastalik Cerrahisi 2012;23(2):88-93.

20. Efstathopoulos DG, Themistocleous GS, Papagelopoulos PJ, Chloros GD, Gerostathopoulos NE, Soucacos PN. Outcome of partial medial epicondylectomy for cubital tunnel syndrome. Clin Orthop Relat Res 2006;444;134-9. [CrossRef] 